\title{
VANGUARDAS E REVOLUÇĀO: A POESIA CONCRETA
}

\author{
HENRIQUE MANUEL ÁVILA ${ }^{1}$
}

ÁVILA, H.M. Vanguardas e revolução: a poesia concreta. Semina: Ci. Soc.JHum., Londrina, v. 13, n. 3, p. 139-147, set. 1992.

RESUMO: Sem se dar conta do quanto de provinciano e de ressentido havia na sua atitude, o movimento brasileiro da poesia concreta pretendeu, nos anos cinqüenta, ter dado um salto qualitativo-revolucionário na evoluçáo das formas da poesia ocidental, adiantando-se assim, em termos técnicos, aos grandes centros do poder cultural e económico na Europa e nos Estados Unidos. Atacada pelos movimentos culturais de esquerda nos anos sessenta, a poesia concreta quis ainda impor a sua forma como 0 único modo eficiente de fazer revoluçáo social através da arte. Mas, já nos anos oitenta, acabou por integrar-se na atmosfera pós-modema de desencanto em relação às revoluçóes sociais e estéticas, o que equivale a reconhecer a debilidade das suas inovaçós formais e a insinceridade dos seus episódicos propósitos critico-sociais. O pouco que ficou de bom da poesia concreta tem sentido inegavelmente progressivo e convêm agora uni-lo ao generoso sonho utópico que subjaz às aparentemente antiart'sticas vanguardas do tipo do Centro Popular de Cultura (CPC).

PALAVRAS-CHAVE: Literatura brasileira; Vanguarda, Sociologia da literatura

Quer por metáfora, quer no sentido real, os teóricos e artistas de vanguarda tiveram de defrontar-se, em vários momentos deste século e em vários lugares, com a idéia de revoluçăo. No Brasil, isso se tornou agudo nas

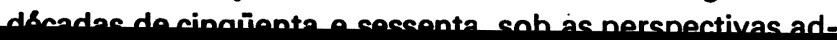

(ou outro planeta) em torno do próprio eixo ou em torno do Sol; e os geómetras constroem a figura sólida do cilindro pela revolução de um plano retangular ao longo de trezentos e sessenta graus. Há sempre, portanto, uma volta ao ponto de partida; o ir em frente é, afinal, um andar para trás. É isso que fundamenta o que podemos chamar oconceito antronolóaico de revolucäo. 
que resolvam os problemas e realizem os desejos sociais que sempre haviam sido frustrados.

Outra explicação antropológica da revolução muito mais desencantada, talvez mesmo com o seu grão de sensatez - é a que se baseia no mito da roda da fortuna (DELAPORTE, 1987). Tudo muda neste mundo, mas a sorte prefere dar à sua roda apenas meia volta de cada vez. Quem estava por cima ficará por baixo: o rico e poderoso passa a pobre e oprimido; em contrapartida, os pobres (alguns....) deste mundo terão a sua época de opulência e mando. Por outras palavras, a revolução substitui os poderosos, mas mantém incólume a injustiça estrutural da sociedade. Ou como pregava a Igreja em bem sucedida estratégia ideológica: que cada um viva virtuosamente de acordo com sua sorte e estado, porque o mesmo Deus que distribui as riquezas e a pobreza também poderá, quando menos se esperar, fazê-la novamente mudar de mãos.

Alguns exemplos: a Revolução Francesa, a revolução por antonomásia, deu corpo ao tempo talvez mais contraditório, convulso e fecundo que as páginas da história registram; mais perto de nós, mas também tensa $e$ viva no quente tempo de quase dois anos, a portuguesa Revolução dos Cravos (1974-1975) ainda nos parece ferir com o sabor forte e primitivo daqueles momentos que acreditavam tudo poder mudar; já da Revolução Russa fica, setenta anos depois, a acusação, certamente injusta em vários pontos, de que apenas deu meia volta à roda da fortuna...

Igualmente, a arte tem tido os seus incandescentes momentos revolucionários, em que se desmoronam os canónes da tradição e tudo regressa ao originário informe, de cujas forças ainda não aproveitadas ou então relegadas ao esquecimento os artistas-demiurgos irão criando as novas formas. Um desses movimentos revolucionários foi o romantismo, embora tenha terminado, numa das suas direçōes, pela renovação (em parte, restauração) das culturas medieval, popular e primitiva de cada nação. Mais radicalmente revolucionárias foram as vanguardas, já neste século, particularmente o dadaísmo e o surrealismo: tudo se negava e destrula, não só a razão, mas também a forma estética e a linguagem, quaisquer que elas fossem; era o caos total e soberano, anterior a toda luz do conhecimento, anterior ao poder organizador de qualquer palavra. Tinha-se chegado ao estado de indiferençiação absoluta e, paradoxalmente, à fonte das potencialidades infinitas. Era a reencarnaçāo moderna dos dilúvios e recriaçōes do mundo das mitologias. Mas com a diferença de que a mitologia de agora se embebia por inteiro na história: o mundo que acabava era o da Europa capitalista, industrial e vitoriana, sob a avalanche de uma guerra e angústia sem precedentes; a partir dal, uns começaram a regredir para a barbárie nazi-fascista, enquanto outros avançavam resolutos para as futuras sociedades dos conselhos populares como na Rússia e, meteoricamente na Hungria e na Alemanha (Munique). Nada de admirar, portanto, que muitos artistas de vanguarda se separassem, optando por objetivos politi- cos opostos, como Marinetti e Maiakóvski. Nada também de admirar que os Impetos vanguardistas fossem dando lugar a estilos artisticos aparentemente moderados, mas conseqũentes e duradouros, como o modernismo e o neo-realismo (ELIADE, 1986).

No Brasil, quem mais se aproximou desse tipo de revolução artistica foi o movimento da Semana de Arte Moderna (1922). A tradição que pontificava na nossa cultura, porém, era bem pouco consistente, enquanto os grupos vanguardistas eram pouco numerosos e relativamente bem comportados, descartada a meia exceção da teoria antropofágica e dos romances parodisticos de Oswald de Andrade. Por isso, não foi necessária uma violência extraordinariamente forte para voltar ao caos potencialmente criador. Mas isso bastou para que a literatura brasileira amadurecesse, de verdade, nas décadas seguintes. Muito mais agressivo na busca do ponto zero da arte, na busca da violência artistica para forjar uma nova e ativa consciência social, foi o diretor teatral José Celso, nos anos 60 e 70, ao encenar 0 rei da vela de Oswald de Andrade e Roda viva de Chico Buarque de Holanda, com a linguagem teatral mais desregrada e excessiva, grotesca e cruel, aparentemente para lá de todos os limites e perspectivas (LINS, 1990; PRADO, 1988). Paradoxalmente, porém, a revolução de José Celso parece ter-se esgotado em si mesma, talvez porque a sua arte se tenha tornado um rito vazio, ineficaz, na mesma proporçảo em que se esforçava por mostrar-se patético. Nem a tentativa contemporånea de espalhar as guerrilhas esquerdistas pelas cidades, campos e montanhas do pais contribuiu para essa subida (ou descida) à plenitude caótica das origens. E em épocas anteriores tinha dado certo: Revoluçāo Francesa e romantismo; vanguardas e guerra de 1914 com a Revolução Russa.s.

Haverá, pois, que reformular o conceito de revolução, agora em sentido marxista, efetivamente histórico. Revoluçāo não significa catástrofe, tão momentânea quanto estuante de energias, mas sim o ápice de um relativamente longo processo de contradiçōes internas, que foram evoluindo e se intensificando até que tiveram de explodir. Segundo o raciocínio marxista, já năo se pode manter o mesmo tipo de divisăo social de poder, propriedade e distribuição dos bens materiais e culturais, depois de terem mudado as tecnologias e os processos de trabalho para a produção de mais e melhores bens de uso humano. $O$ processo, portanto; envolverá a transformaçāo estrutural complexa de uma sociedade, sem que nenhum dos seus setores fique de fora, o que evidentemente inclui a cultura, libertando-a da posiçāo ancilar em que, em parte, servira de legitimaçăo ideolóǵica da situação social derrubada.

Igualmente, $\mathbf{e}$ impossivel aceitar a revolução como volta do mítico caos originário, muito simplesmente porque o tempo histórico e irreversivel, apesar dos retrocessos e desvios sob o ponto de vista axiológico. As contradiçóes que produzem um novo clímax revolucionário representam um avanço sobre as contradiçס̄es da revoluçăo anterior, como a Revolução Russa em relaçăo à Re- 
volução Francesa. A semelhança que se vislumbra, todavia, corr. o caos mítico refere-se à fusão contraditória de energias, aos feitos heróicos e crimes nefandos, aos entusiasmos delirantes, por mais que se queiram definir e clarificar os rumos. Também não se confundirá com a mera restauração de uma sociedade, mesmo recente, porque equivaleria à contra-revoluçăo. Nem sequer se confundirá com o regresso à humanidade da idade de ouro ou do paraiso terrestre, desejos míticos de persistência milenar, nem se confundirá com o comunitarismo das primitivas sociedades sem classes, que parecem ter exercido algum fascínio sobre Marx: tanto o mito edênico quanto o comunitarismo arcaico apenas desempenham o papel, aliás importante, de antítese crítica das iniquas sociedades de castas e de classes; por força da transformação dialética, aqueles ideais superiores integrariam, juntamente com os maióres progressos da tecnologia e da cultura, a futura sociedade perfeita, esta sim o mais sazonado fruto da revolução prevista por Marx e almejada pelos seus seguidores, numa espécie de secularização de sempre renovada esperança judaica na vinda do Messias... É .neste sentido marxista que a revoluçäo se identifica com vanguarda, porque produçāo efetiva do novo em todos os aspectos da humanidade (BLOCH, 1976).

Nos anos cinqüenta e sessenta, acreditou-se firmemente que o Brasil vinha passando por transformaçōes profundas na atividade económica e na consciência social, de modo que estaria para breve a que muitos já chamavam, sem pudor, a "revolução brasileira" (SODRÉ, 1958; PRADO JUNIOR, 1987). E até se acreditava fazê-la sem grandes violências e sobressaltos, graças ao "desenvolvimento" harmónico, planejado e executado sob a sábia e ágil batuta do carismático presidente Juscelino $\mathrm{Ku}$ bitschek, embora poucos anos tenham bastado para denunciar a miragem da revoluçăo pacifica. Mas a cultura não ficou imune ao fascinio dos novos tempos: enquanto a poesia concreta desenvolvia a sua revolução artística, o Centro Popular da Cultura fazia da arte um meio para ajudar a eclodir a revolução social total no país. Destacam-se, num caso e outro, o esforço construtivo e o sentido histórico linear do processo. Inimigas que fossem (e foram!) no plano ideológico-político, as duas tendências culturais filiavam-se a conceitos bem aparentados de revoluçăo e de vanguarda, só que uma das tendências apontava logo para a revolução da sociedade, ao passo que a outra se contentava com o papel, a seu ver privilegiado, de vanguarda no desenvolvimento internacional da poesia e das artes.

\section{II}

Quase ninguém contesta que a poesia concreta ocupou a posição da mais avançada vanguarda na poesia brasileira dos anos 50, lançando ainda ramificaçōes vivas para os anos 60. Poesia tecnicamente complexa, inovadora e sofisticada, acompanhada por talvez ainda mais numerosa e sofisticada teorizaçăo (ou metalinguagem, para respeitarmos a precisão terminológica que o movi- mento tanto prezava), dificilmente se poderia conceber uma vanguarda assim tão afastada da idéia de revoluçăo artistica repentina, enquanto explosão irracional e impetuosa de forças expressivas. Na verdade, os poetas concretos produziam algo bem mais próximo de uma das leis da dialética hegeliano-marxista, ou seja, a lei da transformação da quantidade em qualidade, embora restringindo-a (entendamo-nos!) ao terreno especifico das formas artisticas: de tal maneira e a tal ponto se sucederam, repetiram e acumularam as invençōes técnicas da linguagem poética que acabaram por dar um salto qualitativo, produzindo revolucionariamente uma forma artistica nova: nada menos do que a própria poesia concreta.

Outra vez zelosos da sua diferença terminológicia, os poetas concretos falam em processo culturmorfológico (CAMPOS, 1987). A forma nova, altamente sintética, teria resultado da fusão do que de rigorosamente vivo se tivesse encontrado nas formas poéticas já pretéritas. Do tăo celebrado Mallarmé se elegeu a sintaxe espacial, visual, analógica, corr as diferentes direçōes, sentidos e configuraçōes da composição tipográfica no branco e vazio da página, como em Un coup de dés jamais n'abolira le hasard, produzindo as "subdivisōes prismáticas da idéia". De Ezra Pound se escolheu o método ideográmico, que substitui (ou, pelo menos, suplementa) a sintaxe das línguas analíticas pela força sintética de imagens gráficas e desenhos, signos muitas vezes de valor icónico mas sempre muito estilizados, representando idéias em lugar de fonemas, o que garantiria comıunicação mais rápida e eficaz. Do Joyce de Ulysses e Finnegans Wake, a técnica aproveitada foi o "palimpsesto" ou palavra-montagem, em que numa só se interpenetram duas ou mais palavras, repelindo-se e atraindo-se, para abrir simultåneos vetores comunicativos; dito doutra forma, o signo se torna uma unidade verbi-voco-visual. Finalmente de e.e. cummings (assim mesmo, com iniciais minúsculas) se adotou o princípio sistemático da desintegração ou corte de palavras, nos aspectos mórfico, fonético e gráfico, desestabelecendo continuidades e sobrestabelecendo outras, sempre a potenciar leituras que divergem paralelamente ou se instigam reciprocamente.

Caso extremo de coincidência entre elaboração teórica e produção artistica, o poema concreto se constrói como um objeto, como exato campo relacional de funçōes gráfico-fonéticas, sem apelos patéticos ao absoluto ou confissōes constrangedoras de subjetivismos indisciplinados. De "humano" nem falar, porque se teria degradado num "vocábulo-eunuco, destinado a nomear a esesterilidade ao invés da criaçäo" (CAMPOS, 1987, p. 34). Graças ao método geométrico, matemático, da sua composição, o conteúdo do poema concreto se identificaria plenamente com a sua própria forma ou estrutura: produto extremamente depurado, estaria pronto a ser consumido como um objeto industrial ou para ser lido-interpretado sucessivamente como se de uma partitura musical se tratasse. Nestes tempos de veloz transformação tecnológica, de influência crescente da máquina, de urgente e insistente comunicaçăo publicitária, os poetas 
concretos também chegaram ao poema-cartaz como correlato formal da época, mas felizmente logo viriam a transformá-lo em arri:a de combate contra as más injunçōes da própria sociedade industrial, como se pode ver no famoso poema "coca-cola" de PIGNATARI (apud CAMPUS, 1987, p. 88):

beba coca cola
babe cola
beba coca
babe cola caco
caco
caco
cola
c l o a c a

Do convite-imperativo comercial "beba coca cola" repontam, l cir paranomásia, pela fragmentaçāo e diferente recomposição de palavras, os grotescos "babe" e "caco". Embalados pela repetição caracteristica da linguagem publicitária, os dois termos grotescos alcançam a sintese final, ainda mais grotesca, em "clcaca". Assim, o singular poema-cartaz de Décio Pignatari desmonta e destrói criticamente o sentido comunicativo da própria propaganda, fazendo-a explodir precisamente enquanto forma publicitária.

É a pura forma que parece constituir o conteúdo do poema de José Lino Grünewald, a seguir (CAMPOS \& CAMPOS, 1972, p. 185). Palavras com letras graficamente encorpadas se dispōem na página para construir geometricamente um hiexágono:

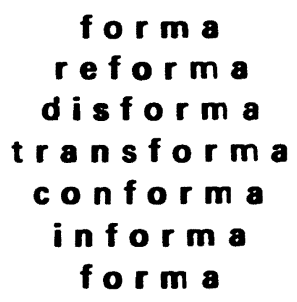

Todos saberri que o hexágono é um poligono de seis lados. Mas esta forma, cuja palavra abre e fecha 0 poema, só atinge a plenitude séxtupla com a ajuda de cinco prefixos, que assim a dinamizam e libertam. $O$ re do repetido recurso ao passado, a contradição dialética das dis-formidades, a solidariedade do con-formar, o conhecimento a fundo das in-formaçōes, tudo será essencial para que a forma se trans-forme, de acordo com a linha central e maior da composição poética. Produção progressiva de novas formas sim, mas năo tảo longe assim do sujo, do feio, do grotesco, do irregular e contraditório das vidas humanas no quotidiano e na histórial Năo resistimos ainda a uma observaçăo que muitos tomaråo por ideologismo vulgar: a "forma" como elemento estático fica à direita do eixo vertical (um tanto tremidom), enquanto os prefixos que insistem na historicizaçăo e concretizaçăo da forma se situam à esquerda... Quando orgulhosamente só, a "forma" está na base: ou no alto do hexágono, como que a igualar conservadores empedernidos e utopistas abstratos na mesma compulsão pelo mundo racicnal e friamente organizado, perfeito, definitivo, em suma inquestionável.

Passemos depressa a Ronalco Azeredo lapud CAMPOS, 1972, p. 195):

$V V V V V V V V V V$
$V V V V V V V V V E$
$V V V V V V V V E L$
$V V V V V V V E L O$
$V V V V V V E L O C$
$V V V V V E L O C I$
$V V V V E L O C I D$
$V V V E L O C I D A$
$V V E L O C I D A D$
$V E L O C I D A D E$

Aparentemente, começamos a isolar-nos na atmosfera rarefeita da máxima assepsia formal. A própria estrutura poemática se comunica imediatamente a si mesma como convếm à grande velocidade e quantidade de "informaçōes" que disputam a atençăo do homem contemporåneo. Temos aqui um retângulo, dividido por uma diagonal em dois triângulos. A novidade que 0 primeiro repete indefinidamente o mesmo signo icónico, o /v/, metaforizando, através do vento, a velocidade típica da civilização contemporånea; entretanto, ficamos no reino do indiferenciado, da continuidade absoluta, que torna tudo igual e uniforme. Já o segundo triângulo se vai progressivamente preenchendo com letras diferentes, com sinais discretos, até formar a própria palavra "velocidade", portanto bem no reino da descontinuidade, da análise, mesmo da sintaxe, se assim nos autorizarem a classificar a inter-relação de letras (fonemas) para constituir um vocábulo, que corporifique uma idéia e entre num discurso. Por mais instantånea, direta e epidérmica que seja, a comunicação poética não prescindirá do descontlnuo e do relacional, que sempre caracterizaram a linguagem humana. Paradoxo magnifico: plasticamente belo e original, este poema acaba por desmentir um dos postulados teóricos pelos quais mais se bateram os poetas concretos.

O ponto-limite, o zênite da evoluçāo das formas, já no interior da poesia concreta, foi instituldo por Décio Pignatari e por Luiz Ângelo Pinto, com o poema-código ou poema semiótico. Depois de terem sepultado o verso e a frase, suprimeri: a palavra, a sllaba e a letra, a fim de inventarem signos visuais radicalmente novos, que dependam de códigos também novos. Acompanhară o poema semiótico uma "chave léxica" para que o leitor possa decodificá-lo. A seguir citaremos um desses poemas de PIGNATARI (apud CAMPOS, 1972, p. 152), mas năo para analist-lo. Se precisou fornecer-nos uma chave léxica, por que o poeta andou perdendo tempo com tais desenhos e suas combinaçס̋s em lugar de escrever um poema com os recursos de que a paleta verbal sempre se tem revelado inesgotável? Em lugar de uma revolução 
formal, o que Décio Pignatari aqui intenta é nada menos do que a morte da poesia.
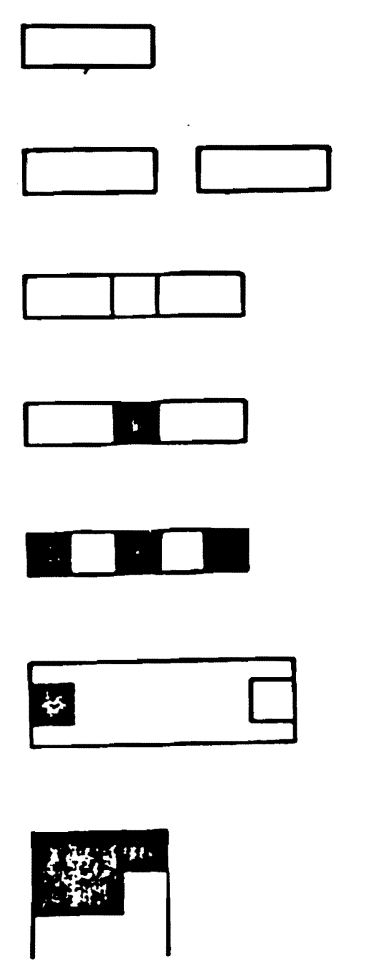

chave léxica

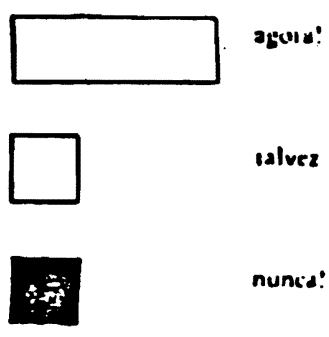

III

Deixando de lado o poema semiótico, já que se reduziu a experiência pontual, sem maiores conseqũências, podemos aceitar a poesia concreta como talvez o mais original aproveitamento estético das chamadas artes gráficas. Pensavam os teóricos do movimento ultrapassar assim a velha tradição, ao mesmo tempo aristocrática e artesanal, da literatura manuscrita, que aparentemente so se deixava transpor para caracteres tipográficos para facilitar a sua comunicaçăo. Já na segunda metade do século $X X$, quando técnicas incomparavelmente mais modernas, como o rádio e a televisăo, avançavam a passos largos noutros paises (e aqui), um tal fascinio pelas técnicas tipográficas só năo provocaria maiores constrangi- mentos porque todos conheclamos o quanto permaneciam rudimentares os hábitos editoriais e tipográficos no Brasil, como aliás competia a um pals subdesenvolvido, tradicionalmente desatento não só à renovação tec:r ológica, mas também aos principais problemas cia cultura. Por outro lado - reconheçamos -, repercutic nos poetas concretos a admiração que Mallarmé votara ao jornal impresso, provavelmente a indústria de transmissāo de not'́cias e opinióes mais avançada e socialmente eficiente que o poeta francês conheceu: a forma do mosaico que, na página jornalistica, tomavam os telegramas das mais diversas origens e sobre os mais dispares (e mesmo disparatados) assuntos, ao lado de artigos, notas, anúncios e talvez poemas ou contos também da mais lata variedade - esse mosaico, dizlamos, anunciaria a forma estética adequada para manifestar o fragmentário, a simultaneidade e a justaposiçāo nervosas e desumanas que definem a vida da sociedade moderna, produzida e condicionada pela revolução industrial (CAMPOS, 1979). Era a revolução industrial que os poetas concretos viam agir no Brasil, mas noutros niveis, talvez bem mais democráticos.

Além do poema-cartaz, com que reagiam aos processos formais da publicidade em crescimento, os poetas concretos manifestavam a sua obsessão tecnicista também quando escolhiam termos do vocabulário tecnoburocrático para aplicá-los metaforicamente à teoria da poesia e das artes. Bastarão alguns exemplos: a recolha de textos da Teoria da poesia concreta (CAMPOS et al., 1987), escritos e publicados de 1950 a 1960, constitui um "plano decenal"; já em 1950, PIGNATARI acha que todo "poema autêntico é (...) uma aventura planificada" (CAMPOS et al., 1987, p. 15); Haroldo de Campos quer que a poesia se faça pelos principios da "matemática da composiçāo" e imite a técnica objetivamente internacional dos "laboratórios de física nuclear" (CAMPOS et al., 1987, p.34 e 96); acima de tudo, o manifesto fundamental de 1958 ostenta o preciso título de "plano-piloto para a poesia concreta" (CAMPOS et al., 1987, p. 156). A denominação idêntica à da parte central de Brasillia, a tecnológica capital do futuro que começava a ser levantada, não deve ser, ao contrário das novelas ruins, uma simples coincidência. Os poetas concretos estiveram ainda entre os primeiros e mais entusiasmados divulgadores dos formalistas russos no Brasil, para os quais a arte residia tão-somente no procedimento técnico empregado para organizar os materiais de que ela é feita.

À primeira vista, é difícil explicar uma tal obsessão pela técnica num pais que, segundo o próprio hino nacional, parecia contente, “deitado eternamente em berço esplêndido". Mas as razōes existem, chamem-lhes pedantismo, provincianismo, deslumbramento ou ressentido complexo de inferioridade.

A verdade $\&$ que a poesia concreta surgiu no tempo em que o Brasil finalmente acordou para a gigantesca tarefa nacional de vencer o atraso, com tudo o que ele significava de miséria, doença, ignorância, dependência dos paises adiantados e até mesmo barbárie. $A$ ferramenta escolhida foi exatamente o desenvolvimento tec- 
nológico e industrial: depois de Getúlio Vargas ter fundado a Companhia Siderúrgica Nacional e a PETROBRÁs a fim de garentir bases sólidas e independentes para a industrializaçăo generalizada, chegou o presidente Juscelino Kubitschek de Oliveira com o seu ambicioso Plano de Metas para, nos cinco anos do seu mandato (1956-1961), colocar o Brasil no mesmo patamar de desenvolvimento que paises desenvolvidos tinham levado cinqüenta anos ou mais a atingir. Enquanto se construla a nova capital, símbolo plástico do novo poder e confiança nacionais, conjugaram-se esforços tais de trabalho e convencimento que poucos setores sociais conseguiram manter-se à margem do processo (CARDOSO, 1978; ALBUQUERQUE, 1981). Nessas circunståncias, era natural que os poetas concretos se unissem, à sua maneira, ao mesmo esforço geral de progresso: a modernização industrial è social que o juscelinismo buscava correspondia à invenção técnico-formal com que o concretismo pretendia pór-se à frente da produção poética internacional; noutras palavras, a revolução artistica era uma das tantas direçōes da revolução total que estaria transformando pacificamente o pals. No momento, não seria fácil a um movimento artistico de um pals atrasado resistir criticamente aos desmandos sociais do progresso, como inversamente fizeram os filósofos da Escola de Frankfurt (HORKHEIMER \& ADORNO, 1974) em relação à reificação desumanizadora das sociedades industriais mais avançadas, como os Estados Unidos e como a Alemanha Federal, está no seu acelerado caminho de reconstrução capitalista.

Relacionada ainda com o que acabamos de dizer, há outra razăo, esta sim provincianamente pedante, para o deslumbramento dos poetas concretos com a técnica, elevada a um tal grau de valia estética que mal encontrará paralelo noutra parte do mundo. E é uma razão que eles provavelmente nunca irão assumir. Trata-se do ressentimento nacionalista brasileiro, de quem precisa vingar-se de ter sido colónia e de continuar sendo hoje um pals atrasado, sempre dependente dos grandes centros político-económicos e culturais da Europa e dos Estados Unidos, não obstante os esporádicos surtos de desenvolvimento num ou outro campo. Tão dolorosa e persistente é a marca do Brasil como colónia e pals de exportaçăo de produtos primários e de importaçăo de produtos industrializados, conhecimentos cientfficos e padröes culturais que CAMPOS \& CAMPOS $(1972$, p. 136) ainda retomam o tópico oswaldiano da "poesia de exportação" para entronizar a poesia concreta no lugar que ela mereceria:

Evidentemente, quando se fala de uma "poesia de exportaçáo", se quer significar uma poesia capaz de criar técnicas novas de validade inclusive internacional, e năo da exportação habitual de matéria prima do exótico, tf́ica de certa literatura brasilieira geralmente divulgada fora de nossas fronteiras.

Mas a exportaçăo-vingança cultural alcança um significado bem maior noutro artigo, assinado apenas por Haroldo de Campos (CAMPOS, 1979). Na história da poesia ocidental moderna, enquanto progressiva invençăo, transformaçăo e mistura de linguagens, tócnicas, formas, gêneros e mesmo media, o Brasil ocuparia dois pontos fulcrais. $O$ grande precursor universal das vanguardas teria sido o brasileiro Sousåndrade, ao escrever O Guesa, principalmente o episódio "Inferno de Wall Street", em que fez uma montagem descontinua com noticias jornalisticas, notas históricas, passos mitológicos, citaçōes, comentários, diálogos laconissimos, palavras e frases cruzadas por várias línguas. Tudo isso antes do genial Mallarmé! E o ponto final, perfeito, para onde convergiram todas as invençōes vanguardistas, voltou a localizar-se no Brasil, no "movimento internacional da poesia concreta", em que pontifica o mesmissimo Haroldo de Campos, ao lado do seu irmão Augusto e de Décio Pignatari. Apesar dos vários méritos da poesia concreta, é deslumbramento demais para quem julgava ter abandonado definitivamente todos os resquicios de subdesenvolvimento cultural.

IV

Embora tenham insistido polemicamente por muito tempo sobre o caráter estritamente técnico-artistico da sua revolução, os principais poetas concretos experimentaram, năo raras vezes, o peso da má consciência quanto à necessidade da revolução económico-social, mesmo de tipo marxista, no Brasil.

Haroldo de Campos, que ainda há pouco citávamos, reconhecia o vergonhoso atraso geral do Brasil, apesar do pretenso alto desenvolvimento da poesia concreta. Para explicar o descompasso, consultava precisamente Marx e Engels (CAMPOS, 1979, p. 287): "As obras intelectuais de uma nação tornam-se propriedade comum de todas". Noutros termos, as naçōes pobres também podem fazer a sua "acumulação intelectual primitiva", sem a qual jamais brotarăo as obras culturais superiores e originais. Mas CAMPOS (1979) menosprezou um sério problema: 0 alto grau de analfabetismo e o reduzido est'mulo estatal e social ao acesso da maioria da população à atividade cultural de boa qualidade dificultarảo a acumulação intelectual primitiva, de modo que a nossa cultura nunca irá além de uns raríssimos gênios, alguns felizmente autênticos, mas outros dos quais será melhor nem falar.

Já antes Haroldo de Campos andara catando argumento definitivo, para justificar a absoluta autonomia formal da poesia concreta, nos escritos de uma autoridade que provavelmente nenhum dos mais inflamados partidários da literatura engagée ousaria refutar. Nada menos do que SARTRE, que em 1948 publicara 0 que é literatura? (SARTRE, 1978). CAMPOS agarrava-se à distinçåo sartriana entre prosa e poesia: a primeira constava de palavras-signos, as quais, por definição, referenciam a realidade exterior, obrigando assim o escritor ao compromisso de desvelar as contradiçōes sociais para 
que os seus leitores intervenham conscientemente no processo histórico; por sua vez, a poesia se identifica com palavras-coisas, que partilham com os sons da música e as cores e linhas da pintura o privilégio da auto-suficiência estética, da sensualidade corpórea, da validade por si mesma, de tal maneira que seria uma "tolice" exigir qualquer engagement poético (CAMPOS, 1987). Era o álibi perfeito para o tempo em que se começavam a acirrar as discussōs na sociedade brasileira: os concretistas não faziam literatura comprometida com a revolução social que parecia a caminho, precisamente porque não escreviam prosa: eles produziam poesia!

As coisas, porém, eram bem mais complexas, conforme viria a reconhecer outro membro da trlade concreta, numa inteligente comunicação ao II Congresso Brasileiro de Crítica e História Literária, reunido em Assis (São Paulo), em 1961. O ambicioso Plano juscelinista de Metas começava a cobrar a pesada conta da inflação, desigualdades regionais e sociais e dependência económica externa, o que acendia, com redobrada força, os rastilhos da cólera nacionalista e dos protestos camponeses e operários e até de setores médios. Nessas coordenadas, Décio Pignatari compreendeu como era impossivel prosseguir com o olimpico alheamento da poesia que, a despeito de tudo, teimava em chamar-se concreta.

Por isso, Décio Pignatari volta a Sartre, mas segundo uma leitura dialética. A bem dizer, não há poesia nem prosa inteiramente puras, desde que, com a revolução industrial e a consolidação da sociedade burguesa, entrou em crise a função social do poeta. Ao mesmo tempo, num conflito que jamais parece resolver-se, o poeta critica a antiga forma artesanal de escrever e o modo de viver que a nova sociedade industrial impós. Na primeira linha, obriga-se à poesia como pura construçăo; na segunda, à simples expressão prosaica, conteudística, do protesto contra a sociedade. É a terrível dialética do fracasso-êxito, nas palavras de Sartre: o éxito da poesia como pura comunicação, năo mediada por signos, da recusa à sociedade corresponde ao seu completo fracasso como informação, esta sim feita de signos. Quanto mais cede à tentação da informaçäo importante, tanto mais perde a sua condição de poesia, a única "atitude original da poesia contemporånea" (PIGNATARI, 1971, p. 101). Mas o êxito da poesia pura jamais deixa de ser também fracasso por causa da má consciência que prossegue dilacerando o poeta, num tempo e.sociedade historicamente maus.

É esse conflito que Pignatari divisa em Carlos Drummond de Andrade e em Joảo Cabral de Melo Neto. Em Sentimento do mundo e em Jose, Drummond balança entre o conteúdo-expressão e o conteúdo-construçăo, denunciando os medos daquela época de ditadores com a "rápida montagem ideogrâmica do verso-prosa 'jornalístico" " (PIGNATARI, 1971, p. 96), mas já acentua a nota participante de Rosa do povo, quase a transformá-la de poesia em prosa. $O$ que não impediu Pignatari de garimpar, em Rosa do povo, esta impressionante declaraçāo de Drummond ao poema: "os temas passam / (...) mas tu resistes" (PIGNATARI, 1971, p. 99).
Joåo Cabral teria sido exemplar no seu projeto poético inicial como conteúdo-construçăo, tendo parado a um passo do supremo salto qualitativo da poesia concreta, mas acabou por se prosificar, regredindo às formas artesanais de Morte e vida severina, para passar informação participante sobre o Nordeste subdesenvolvido e miserável. Diagnosticado assim o problema, a poesia concreta terá também de mudar a sua solução, tornando participante o seu conteúdo-construção (PIGNATARI, 1971, p. 108): "A poesia concreta vai dar, só tem de dar, o pulo conteudístico-semåntico-participante. Quando - e quem - não se sabe".

Essa ignorância tão inesperadamente humilde não durou muito. Contraditoriamente os irmãos Campos remontam a 1957 o início das preocupaçōes com "problemas de ordem semântica, problemas de engajamento" (SIMON \& DANTAS, 1987, p. 37), em poemas como "coca-cola" de Décio Pignatari e "petróleo" de José Lino Grünewald. Vale a pena uma vista de olhos ao segundo poema:

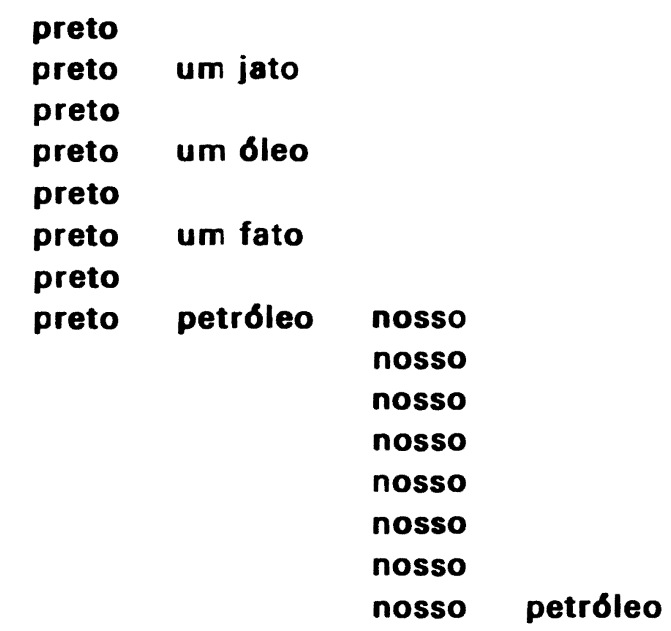

É obvia, no poema, a frase que comandou a luta nacionalista pública pela criação da PETROBRÁS em regime de monopólio: "O petróleo é nosso!" Não se trata, portanto, de antipropaganda, do tipo do poema "coca cola" de Décio Pignatari, que comentamos algumas páginas antes; aliás, é assim que os dois textos concretos coincidem na mesma atitude nacionalista. $O$ que, todavia, agora nos importa assinalar são as duas colunas verticais e compactas do poema: uma, em cima e à esquerda, repetindo oito vezes a palavra "preto"; a outra, em baixo e à direita, repetindo o mesmo número de vezes a palavra "nosso". Para alguns leitores, a coluna do "preto" apenas anunciaria por paronomásia, recurso técnico muito dos concretistas, o nosso "petróleo", solidamente fincado na base direita do texto. Mas preferimos outra leitura, que integra as palavras da segunda coluna: se somos um pais de "pretos", se o "preto" e "nosso", com tudo o que isso implica de feiúra, falta de higiene, ignorância, atraso e barbárie, segundo os padrōes "brancos" dos paises ditos imperialistas, como a branca América do Norte, então que esses paises se mostrem coerentes com a sua ideo- 
logia até o fim e nos deixem tudo o que é "preto", al sobretudo incluindo o petróleo, que antes de refinado também costuma ser de cor escura.

Certamente haverá outros poemas de agudo corte crítico no meio da produção dos poetas concretos. Infelizmente, porém, parece que os fazem a contragosto. Nesse sentido, é emblemático o post-scriptum que Augusto de Campos, Décio Pignatari e Haroldo de Campos adicionaram ao seu principal manifesto (o "plano-piloto para poesia concreta"l, três anos depois, em 1961: "sem forma revolucionária não há arte revolucionária" (maiacóvski) (sic) (CAMPOS, 1987, p. 158). Uma vez mais, vão buscar o argumento de autoridade ao campo do adversário. E principalmente dão ao post-scriptum um ar de reparação tardia de um lapso de memória: ora FREUD (1981) ensinou há muito temo que só se esquece o que, no fundo, se prefere esquecer... Mesmo com tais reservas, a época obrigava a ser revolucionário no campo social quem se quisesse segurar na crista do novo. Tempo virá, porém, em que o "novo" deixará paradoxalmente de ser novo, para ser PÓSTUDO e EXTUDO, num poema concreto publicado, em 1985, por Augusto de Campos (apud SCHWARZ, 1987, p. 57).

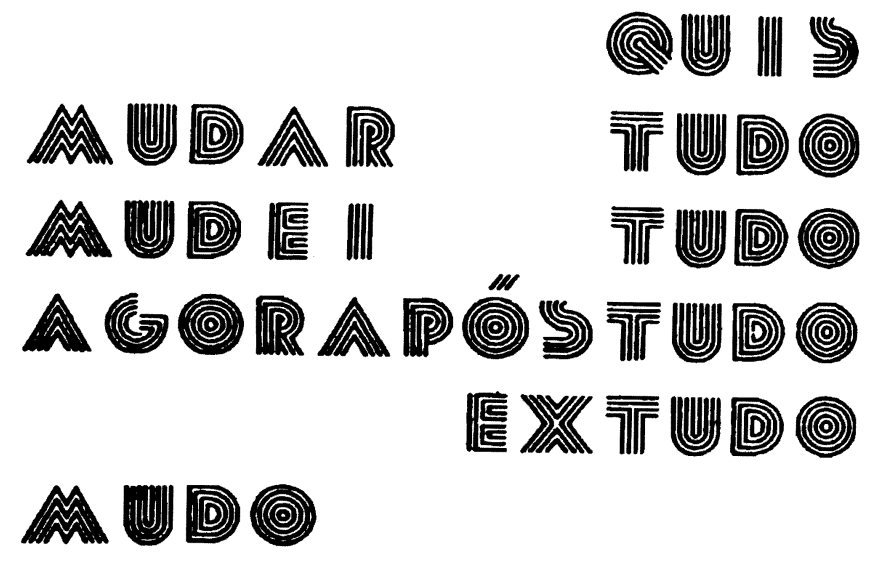

Lida como verbo, a última palavra (MUDO) afirma o propósito de mudar sempre, apesar de tudo. Mas o poema nåo traz qualquer inovação técnico-formal em relação às produçōes clássicas do movimento, depois de quase trés décadas, o que nos autoriza a ler aquela palavra como adjetivo: o poeta terminou "mudo", ou seja, fracassaram os intentos revolucionários da poesia concreta. Não propriamente as preocupaçōes crítico-sociais, já de si episódicas e epidérmicas, que nem o Centro Popular de Cultura e movimentos aparentados conseguiram manter, mas sobretudo as grandes pretensōes de revolução artistico-formal, que não tiveram muito melhor sorte. Além de uns poucos poemas efetivamente bons, ficaram alguns procedimentos técnicos inovadores, e nem sequer os mais radicais, para o repertório de que se servem os poetas da atualidade. Embora magro, tal resultado artistico anuncia um sentido progressivo, o qual só tomará corpo se se encontrar com a utopia subjacente às aparentemente antiartisticas vanguardas que, nos anos 60 , se opuseram à poesia concreta. É por isso que vamos estudá-las num próximo artigo.

ÁVILA, H.M. Vanguards and revolution: the concrete poetry. Semina:Ci. Soc./Hum., Londrina, v. 13, n. 3, p. 139-147, Sept. 1992.

ABSTRACT: With no regards to the provincialism ant the resentment present in its attitude, the Brazlian Concrete Poetry movement had the intention, in the mid 50s, to haven taken a major qualitative-revolutionary step towards the evolution of the west world poetry forms, surpassing insofar, at least in technical terms, the great cultural and economic power centers of Europe and North America. Harshened by the leftist cultural movements of the sixties, the concrete poetry saw its form as the only efficient way to render social revolution through the arts. But, in the eighties, it has integrated itself in the post-modern atmosphere of disenchantment in relation to the esthetic and social revolutions, that is to say, it recognized the feebleness of its formal innovations and lack of sincerity of its social-criticism. The good of what is left has undoubtedly a progressive intent, and deserves now a place along with the generous utopic dream underlying the seemingly anti-artistic vanguards like the Centro Popular de Cultura (CPC). 


\section{REFERÉNCIAS BIBLIOGRÁfICAS}

ALBUQuerQue, Manoel Maurfcio de. Pequena história da formaçáo social brasileira. Rlo de Janeiro: Graal, 1981. p. $461-477$.

BLOCH, Ernst. Le principe Espérance. Paris: Gallimard, 1976. v. 1, p. $239-247$.

CAMPOS, Augusto de; PIGNATARI, Decio; CAMPOS, Haroldo de. Teoria da poesia concreta: textos criticos e manifestos 1950-1960. 3. ed. Sao Paulo: Braslliense, 1987.

CAMPOS, Haroldo de. Ruptura dos gêneros na literatura latino-americana. In: FERNÁNDEZ MORENO, César (coord.) América Latina em sua literatura. Sáo Paulo: Perspectiva, 1979.

CAMPOS, Haroldo de. Poesia e paralso perdido. In: CAMPOS, Haroldo de et al. Teoria da poesia concreta. 3. ed. Såo Paulo: Brasillense, 1987.

CAMPOS, Haroido de; CAMPOS, Augusto de. 0 grupo concretista. In: AZEVEDO FILHO, Leodegdíro A. de (org.). Poetas do modernisma Brasilia: Instituto Nacional do Livro, 1972. v. 6, p. 185.

CARDOSO, Miriam Limoeiro. Ideologia do desenvolvimento: Bras" JK-JQ. 2. ed. Rlo de Janeiro: Paz e Terra, 1978.

DELAPORTE, André. L'idøé d'égalitê en France au XVIII e siécle. Paris: PUF, 1987. p. 132-135.

ELLADE, Mircea. Mito e realidade. 2. ed. Săo Paulo: Perspectva, 1986. p. 162-163.

FREUD, Sigmund. Obras completas. 4.ed. Madrid: Biblloteca Nueva, 1981. v. 1, p. 851-857: Psicopotalogla de la vida cotidlana.
HOBBES, Thomas. Leviata ou materia, forma, e poder de um estado eclesiástico e civil 2. ed. S.o Paulo: Abril Cultural, 1979. p. 7477.

HORKHEIMER, Max; ADORNO, Thoodor $W$. La dialectique de la raison. Paris: Gallimard, 1974.

LINS, Ronaldo Lima. Violéncia e literatura. Rlo de Janeiro: Tempo Braslleiro, 1990. p. 134-137.

PIGNATARI, Déclo. Contracomunicaçấo. Sáo Paulo: Perspectiva, 1971.

PRADO, Décio de Almeida. O teatro brasileiro moderna. Såo Paulo: Perspctiva/USP, 1988. p. 112-115.

PRADO JUNIOR, Caio. A revoluçáo brasileira 7. ed. Săo Paulo: Brasillense, 1987.

ROUSSEAU, Jean-Jacques. Do contrato social... Säo Paulo: Abril Culturai, 1973. p. 243-265: Discurso sobre a origem e os fundamentos da desigualdade entre os homens.

SARTRE, Jean-Paul. Qu'est-ce que la littérature? Paris: Gallimard, 1978.

SCHWARZ, Roberto. Que horas são? Såo Paulo: Companhla das Letras, 1987. p. 57: Marco histórico.

SIMON, lumna Maria; DANTAS, Vinicius. Poesia concreta. Så Paulo: Abril Educação, 1982.

SODRE, Nelson Werneck. Introdução à revoluçâo brasileira. Rio de Janeiro: J. Olymplo, 1958.

Recebido para publicaçảo em 28/2/92 